V. Schmidt $\cdot$ S. Zander $\cdot$ W. Körting $\cdot$ K. Broeg $\cdot$

H. von Westernhagen $\cdot$ H. Dizer $\cdot$ P. D. Hansen •

A. Skouras • D. Steinhagen

\title{
Parasites of flounder (Platichthys flesus L.) from the German Bight, North Sea, and their potential use in biological effects monitoring
}

\section{Pollution effects on the parasite community and a comparison to biomarker responses}

Received: 13 March 2003 / Revised: 11 June 2003 / Accepted: 3 July 2003 / Published online: 15 August 2003

(C) Springer-Verlag and AWI 2003

\begin{abstract}
In the frame of an integrated biological effect monitoring programme, the parasite community of flounder (Platichthys flesus) was investigated at different locations in the German Bight from 1995 to 2000. In order to assess the impact of environmental contamination caused by anthropogenic activities on the parasite community, selected parasitological parameters that displayed significant differences between the sampling sites were subjected to correlation analyses with site-specific contamination and individual pollution loads of their fish hosts. In addition, correlation analyses were conducted with the responses of selected genetic, biochemical, histopathological, physiological and immunological parameters of fish, used as potential biomarkers. In total, 802 flounder were analysed for these parameters. Information on the chemical background at the sampling sites was derived from sediment samples and from 120 samples of blue mussel (Mytilus edulis) tissue, collected at each of the sampling sites. Based on chemical data available from the sediment and blue mussel samples, a pollution gradient could be established between the sampling sites for individual contaminants. The relative abundance of Acanthochondria cornuta, Cucullanus heterochrous and Zoogonoides viviparus, and the community
\end{abstract}

Communicated by H. von Westernhagen, A. Diamant

V. Schmidt · S. Zander · W. Körting · A. Skouras ·

D. Steinhagen $(\bullet)$

Fish Disease Research Unit,

School of Veterinary Medicine,

Bünteweg 17, 30559 Hannover, Germany

e-mail: dieter.steinhagen@tiho-hannover.de

K. Broeg $\cdot$ H. von Westernhagen

Alfred-Wegener Institute for Polar and Marine Research,

Am Handelshafen 12, 27570 Bremerhaven, Germany

H. Dizer · P. D. Hansen

Institute of Ecological Research and Technology,

Department of Ecotoxicology,

Berlin Technical University,

Berlin, Germany measures species richness and number of heteroxenous species decreased with increasing concentrations of individual heavy metals or hydrocarbons in sediment and blue mussel samples. Most of the parasitological parameters significantly reflected the established sitespecific contamination gradient, when data were pooled over all sampling campaigns. Significant correlations were also found with the contamination level of individual flounder. The parasitological parameters included the parasite species Lepeophtheirus pectoralis and Lernaeocera branchialis, which were not correlated to sitespecific contamination. Several biomarkers were significantly correlated to the abundance of parasitic copepods A. cornuta, Lernaeocera branchialis and Lepeophtheirus pectoralis and to parasite community parameters. The results showed that the abundance of several metazoan parasite species, species richness and parasite diversity were reduced in contaminated habitats, and that differences between sites were not only related to natural factors, such as salinity, but also to pollution-induced stress. Thus, it can be concluded that the parasite community of fish responds to the level of pollution at a specific site as well as to residues of xenobiotics in individual fish. These findings give indications that the parasite community of fish is a valuable parameter for the assessment of ecological consequences of chemical contamination in aquatic habitats.

Keywords Pollution monitoring - Platichthys flesus . Parasite community $\cdot$ Biomarker $\cdot$ Bioindicator

\section{Introduction}

Field studies on bioassessment of environmental challenge should include a combination of rapidly responding, sensitive biomarkers of pollution exposure and more ecologically relevant bioindicators, which integrate the effects of various stressors (Adams 2002). 
In general, biomarkers are used to indicate exposure of an organism to a stressor and help to identify the mechanistic basis of causal relationships between stressors and their effects. They are mainly measured at the suborganism level, are sensitive to stressors and show a direct, often highly variable response to these stressors on a short timescale (van der Oost et al. 2003). Bioindicators respond at higher levels of biological organisation, like the population or community level. They are of high ecological significance but, due to the complexity of processes in population and community dynamics, provide little information for helping to understand the underlying causal mechanisms between stressors and effects. Their sensitivity to specific stressors is low and they tend to respond to effects of multiple stressors over a large spatial and temporal scale (Adams 2002). A combined use of biomarkers and bioindicators, with a focus on the organism level, could provide a link between mechanistic understanding and the ecological consequences of pollution exposure, and increase the ability to interpret biological data (Adams 2002).

The use of fish parasites as indicators for marine pollution has been widely and controversially discussed over the last few years. Distribution and infection levels of parasites are not only influenced by environmental contaminants but also by a variety of natural factors (Möller 1978; Khan and Thulin 1991; MacKenzie et al. 1995; Kennedy 1997; Overstreet 1997). Therefore, it is often recommended (Gelnar et al. 1997; Khan and Payne 1997; Overstreet 1997) that in pollution monitoring studies, parasitological data should be accompanied by other types of data such as analytical chemistry or biochemical biomarkers.

In the present study, environmental deterioration was assessed in the frame of an integrated biological effect monitoring programme. The parasite community of flounder (Platichthys flesus L.) was investigated at different sites in the German Bight over a period of 6 years and tested as a potential indicator of anthropogenic impact at the population and community level.

The basic assumptions were that biotic diversity is highest in undisturbed habitats, whereas man-made stress, such as chemical pollution, may lead to a loss of species and a reduction of diversity (Kennedy 1997).

In the present monitoring programme, standard chemical parameters as well as a set of genetic, biochemical, physiological and immunological biomarkers, which were partly recommended as standard methods for general monitoring of the biological effects of contaminants (van der Oost et al. 2003), were sampled and evaluated from the same individual fish, in addition to an assessment of infection parameters of the parasite community. In this paper, the parasitological data were compared to site- and host-specific residue analyses and to responses of the biomarkers under study.

\section{Methods}

Sampling

During spring and autumn of 1995-1997 and 1999-2000, 802 individuals of European flounder (Platichthys flesus L.) were sampled by research vessel trawl catches at five different locations (Elbe estuary, Helgoland, Outer Eider estuary, Inner Eider estuary, Spiekeroog) in the German Bight, North Sea. The stations were determined by their geographical positions.

To avoid size or age effects, only individuals of a narrow size range (18-25 cm total length) were included in the analysis. Ectoand endoparasites were collected from the fish. In addition, biometric, biochemical and immunological measurements were taken from the same individuals. Chemical analysis was performed on the filet of the same individuals. Details of sampling, examination of flounder and numbers of evaluated fish specimen for each sampling period at each location have been described elsewhere (Schmidt et al. 2003a). A list of the parasite taxa recorded during the course of the study, information about their infection levels and parasite community characteristics at the sampling locations have also been presented in detail previously (Schmidt et al. 2003a, 2003b).

Parameters under study

In the present study, those parasitological parameters which indicated differences between the sampling locations, and were therefore used for correlation analyses, are the following: abundance of Trichodina spp., Acanthochondria cornuta, Lepeophtheirus pectoralis, Lernaeocera branchialis, metacercaria of an undetermined trematode species, Zoogonoides viviparus, Cucullanus heterochrous and the community measurements species richness, number of heteroxenous species, number of macroparasite individuals, Shannon-Wiener index of diversity and inverse Simpson's index of diversity. All measurements were calculated for individual fish, the indices were used according to Magurran (1988), and abundance according to Bush et al. (1997).

The same fish individuals which were used for parasitological investigations were also analysed for genetic, biochemical, physiological, histopathological and immunological parameters. The following parameters were incorporated into the correlation analysis of this paper (detailed description of the parameters and the applied methods are given in the respective references):

1. Choline esterase activity in flounder brain (ChE-Br) (Dizer et al. 2003)

2. Choline esterase activity in flounder muscle (ChE-f) (Dizer et al. 2003)

3. DNA-unwinding (DNA-f), DNA strand breaks in hepatocytes (Dizer et al. 2003)

4. EROD activity (EROD), the activity of cytochrome P450dependent monooxygenase ethoxyresorufin- $O$-deethylase (Broeg et al. 1999)

5. Lipids: accumulation of neutral lipids in flounder liver (Broeg et al. 1999)

6. Lysosomal stability, the membrane stability of hepatocyte lysosomes. LY1: type of lysosomes which has an early membrane breakdown; LY2: late membrane breakdown (Broeg et al. 1999)

7. Lysozyme activity (Lys) in flounder plasma (Skouras et al. 2003)

8. Macrophage aggregate area (MAA), the mean size of macrophage aggregates in flounder liver (Broeg et al. 1999)

9. Macrophage aggregate activity (MAM), the activity of acid phosphatase in macrophage aggregates of flounder liver (Broeg et al. 1999)

10. Pinocytosis (Pin): uptake of neutral red by head kidney phagocytes (Skouras et al. 2003) 
Table 1 Correlation analysis of parasite infection parameters of male and female flounder to residues in sediments and blue mussel (Mytilus edulis) tissue from the same geographic location. Correlation coefficients and the level of significance are given. Significant correlations are additionally marked in bold. Acan Acanthochondria cornuta; Cuc Cucullanus heterochrous; Lep Lepeophtheirus pectoralis; Lern Lernaeocera branchialis; Met Metacercaria of an undetermined trematode species; Trich Tri- chodina spp.; Zoog Zoogonoides viviparus; $N$ number of macroparasite individuals; $S$ species richness; $D D D$ 1,1-dichloro-2.2-bis $(p$ chlorophenyl) ethane; $D D E$ 1,1-dichloro-2.2-bis(p-chlorophenyl) ethylene; $H C H$ hexachlorcyclohexane; $P C B$ polychlorinated biphenyls; $\sum P C B s$ sum of PCB 28, 52, 101, 118, 138, 153, 180; 1/D inverse Simpson's Index of diversity; $H^{\prime}$ Shannon-Wiener Index of diversity, $H_{s p}$ number of heteroxenous species

\begin{tabular}{|c|c|c|c|c|c|c|c|c|c|c|c|c|c|}
\hline \multicolumn{2}{|c|}{ Sediment residues } & \multicolumn{9}{|c|}{ Abundance of: } & \multicolumn{3}{|c|}{ Community measurements } \\
\hline Residues & $n$ (samples) & Trich & Acan & Lep & Lern & Meta & Zoog & $\mathrm{Cuc}$ & $S$ & $N$ & $H_{\mathrm{sp}}$ & $H^{\prime}$ & $1 / D$ \\
\hline $\begin{array}{l}\text { Mercury }{ }^{\mathrm{a}} \\
\text { Cadmium } \\
\text { Copper }^{\mathrm{b}} \\
\text { Lead }^{\mathrm{b}} \\
\text { Iron }^{\mathrm{a}} \\
\text { Manganese }^{\mathrm{a}} \\
\text { Zinc }^{\mathrm{a}} \\
\text { Nickel }^{\mathrm{a}} \\
\text { Aluminium }^{\mathrm{a}} \\
\text { Chromium }^{\mathrm{b}} \\
\text { PCB } 138^{\mathrm{c}} \\
\text { PCB } 153^{\mathrm{c}} \\
\text { EPCBs }\end{array}$ & $\begin{array}{r}6 \\
14 \\
14 \\
14 \\
6 \\
6 \\
6 \\
6 \\
6 \\
14 \\
8 \\
8 \\
8\end{array}$ & $\begin{array}{l}0.54 \\
0.38 \\
\mathbf{0 . 5 4} * \\
0.39 \\
0.49 \\
0.54 \\
0.49 \\
0.49 \\
0.49 \\
0.36 \\
0.31 \\
0.34 \\
0.12\end{array}$ & $\begin{array}{l}-0.60 \\
-0.24 \\
-\mathbf{0 . 6 3} * \\
-\mathbf{0 . 5 8} \\
-0.54 \\
-0.60 \\
-0.54 \\
-0.54 \\
-0.54 \\
-0.48 \\
-\mathbf{0 . 8 3} * \\
-\mathbf{0 . 8 8} * \\
-\mathbf{0 . 7 1} *\end{array}$ & $\begin{array}{r}-0.37 \\
0.14 \\
-0.04 \\
-0.01 \\
-0.47 \\
-0.37 \\
-0.49 \\
-0.49 \\
-0.49 \\
0.02 \\
-0.05 \\
-0.12 \\
0.00\end{array}$ & $\begin{array}{r}0.03 \\
0.02 \\
-0.26 \\
-0.21 \\
0.09 \\
0.03 \\
0.09 \\
0.09 \\
0.09 \\
-0.19 \\
-0.24 \\
-0.19 \\
-0.21\end{array}$ & $\begin{array}{r}-0.09 \\
-0.06 \\
-0.08 \\
-0.02 \\
0.09 \\
-0.09 \\
0.09 \\
0.09 \\
0.09 \\
0.01 \\
-0.43 \\
-0.36 \\
-0.43\end{array}$ & $\begin{array}{l}-\mathbf{0 . 9 4} * * \\
-\mathbf{0 . 7 0} * * \\
-0.49 \\
-0.34 \\
-\mathbf{0 . 8 9} * \\
-\mathbf{0 . 9 4} * * \\
-\mathbf{0 . 8 9} * \\
-\mathbf{0 . 8 9} * \\
-\mathbf{0 . 8 9} * \\
-0.11 \\
-\mathbf{0 . 7 6} * \\
-\mathbf{0 . 7 9} * \\
-0.63\end{array}$ & $\begin{array}{l}-\mathbf{0 . 9 4} * * \\
-0.44 \\
-\mathbf{0 . 7 4} * * \\
-\mathbf{0 . 6 4} * \\
-\mathbf{0 . 8 9} * \\
\mathbf{- 0 . 9 4}^{*} * \\
-\mathbf{0 . 8 9} * \\
\mathbf{- 0 . 8 9}^{*} \\
-\mathbf{0 . 8 9} * \\
-\mathbf{0 . 6 2} * \\
-0.40 \\
-0.50 \\
-0.38\end{array}$ & 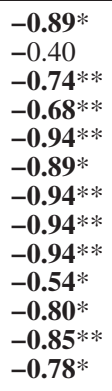 & 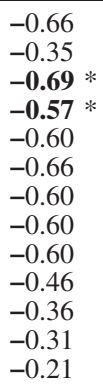 & $\begin{array}{l}-\mathbf{0 . 8 9} * \\
-0.39 \\
-\mathbf{0 . 7 5} * * \\
-\mathbf{0 . 6 7} * * \\
-\mathbf{0 . 9 4} * * \\
-\mathbf{0 . 8 9} * \\
-\mathbf{0 . 9 4} * * \\
\mathbf{- 0 . 9 4}^{*} * \\
-\mathbf{0 . 9 4} * * \\
-\mathbf{0 . 5 7} * \\
-\mathbf{0 . 7 4} * \\
-\mathbf{0 . 7 9} * \\
-0.62\end{array}$ & $\begin{array}{l}-0.77 \\
-0.14 \\
-\mathbf{0 . 5 6} \\
-0.51 \\
-\mathbf{0 . 8 3} \\
-0.77 \\
-\mathbf{0 . 8 3} \\
-\mathbf{0 . 8 3} \\
-\mathbf{0 . 8 3} \\
-0.41 \\
-0.64 \\
-\mathbf{0 . 7 4} \\
-0.52\end{array}$ & $\begin{array}{l}-0.77 \\
-0.06 \\
-0.34 \\
-0.36 \\
-\mathbf{0 . 8 3}^{*} \\
-0.77 \\
\mathbf{- 0 . 8 3}^{*} \\
\mathbf{- 0 . 8 3}^{*} \\
-\mathbf{0 . 8 3}^{*} \\
-0.40 \\
-0.33 \\
-0.45 \\
-0.38\end{array}$ \\
\hline \multicolumn{2}{|c|}{ M. edulis residues } & \multicolumn{9}{|c|}{ Abundance of: } & \multicolumn{3}{|c|}{ Community measurements } \\
\hline Residues & $n$ (samples) & Trich & Acan & Lep & Lern & Meta & Zoog & Cuc & $S$ & $N$ & $H_{\mathrm{sp}}$ & $H^{\prime}$ & $1 / D$ \\
\hline $\begin{array}{l}>\text { Cadmium }^{d} \\
\beta-\mathrm{HCH}^{\mathrm{c}} \\
\text { p.p-DDE }{ }^{\mathrm{c}} \\
\text { p,p DDD }{ }^{\mathrm{c}} \\
\sum_{\mathrm{PCBs}}{ }^{\mathrm{c}}\end{array}$ & $\begin{array}{l}18 \\
12 \\
12 \\
12 \\
12\end{array}$ & $\begin{array}{l}0.62 * * \\
0.74 * * \\
0.63 * \\
0.68 * \\
0.87 * * *\end{array}$ & $\begin{array}{l}-\mathbf{0 . 7 3} * * * \\
-\mathbf{0 . 6 0} * \\
-0.56 \\
-\mathbf{0 . 7 5} * * \\
-\mathbf{0 . 8 8} * * *\end{array}$ & $\begin{array}{r}-0.38 \\
-0.22 \\
0.00 \\
0.14 \\
-0.33\end{array}$ & $\begin{array}{l}-0.25 \\
-0.44 \\
-0.55 \\
-0.34 \\
-0.38\end{array}$ & $\begin{array}{l}-0.04 \\
-0.26 \\
-0.52 \\
-0.25 \\
-0.38\end{array}$ & $\begin{array}{l}-\mathbf{0 . 4 8} * \\
-\mathbf{0 . 5 9} * \\
-0.51 \\
-\mathbf{0 . 6 8} * \\
-0.49\end{array}$ & $\begin{array}{l}-\mathbf{0 . 5 8} * \\
-0.56 \\
-0.33 \\
-\mathbf{0 . 6 4} * \\
-\mathbf{0 . 8 2} * * *\end{array}$ & $\begin{array}{l}-\mathbf{0 . 5 1} * \\
-\mathbf{0 . 5 8} * \\
-0.51 \\
-\mathbf{0 . 7 2} * * \\
-\mathbf{0 . 7 4} * *\end{array}$ & $\begin{array}{l}-0.40 \\
-\mathbf{0 . 7 8} * * \\
-\mathbf{0 . 7 7} * * \\
-0.49 \\
-\mathbf{0 . 6 8} *\end{array}$ & $\begin{array}{l}-0.34 \\
-\mathbf{0 . 7 3} * * \\
-\mathbf{0 . 6 4} * \\
-\mathbf{0 . 7 6} * * \\
-\mathbf{0 . 8 0} * * *\end{array}$ & $\begin{array}{l}-\mathbf{0 . 6 5} * * \\
\mathbf{- 0 . 6 2} * \\
-0.41 \\
-\mathbf{0 . 5 9} * \\
-\mathbf{0 . 9 0} * * *\end{array}$ & $\begin{array}{l}-\mathbf{0 . 5 4} * \\
-0.47 \\
-0.19 \\
-0.51 \\
-\mathbf{0 . 7 8} * *\end{array}$ \\
\hline
\end{tabular}

$* P<0.05$, ** $P<0.01, * * * P<0.001$

a Samples were taken in 1996

b Samples were taken in 1996, 1999 and 2000

c Samples were taken during 1999 to 2000

d Samples were taken from 1997 to 2000

Table 2 Correlation analysis of parasite infection parameters to residues in the muscle of male and female flounder $(n=185)$ over the years 1999 to 2000. Parasite infection parameters and chemical analysis were performed on the same flounder individuals. Correlation coefficients and the level of significance are given. Significant correlations are additionally marked in bold. Acan Acanthochondria cornuta; Cuc Cucullanus heterochrous; Lep Lepeophtheirus pectoralis; Lern Lernaeocera branchialis; Met Metacercaria of an undetermined trematode species; Trich Tri- chodina spp.; Zoog Zoogonoides viviparus; $N$ number of macroparasite individuals; $S$ species richness; $D D D$ 1,1-dichloro-2.2-bis(pchlorophenyl) ethane; $D D E$ 1,1-dichloro-2.2-bis(p-chlorophenyl) ethylene; $H C B$ hexachlorobenzene; $O C S$ octachlorostyrole; $P C B$ polychlorinated biphenyls; $\sum P C B s$ sum of PCB 28, 52, 101, 118, $138,153,180 ; 1 / D$ inverse Simpson's Index of diversity; $H^{\prime}$ Shannon-Wiener Index of diversity, $H_{s p}$ number of heteroxenous species

\begin{tabular}{|c|c|c|c|c|c|c|c|c|c|c|c|c|}
\hline & \multicolumn{9}{|c|}{ Abundance of: } & \multicolumn{3}{|c|}{ Community measurements } \\
\hline & Trich & Acan & Lep & Lern & Meta & Zoog & Cuc & $S$ & $N$ & $H_{\mathrm{sp}}$ & $H^{\prime}$ & $1 / D$ \\
\hline Mercury & -0.01 & $0.18^{*}$ & $0.23 * *$ & $0.30 * * *$ & 0.16 & 0.06 & $0.18 *$ & $0.27 * *$ & $0.28 * * *$ & 0.15 & 0.11 & 0.05 \\
\hline $\mathrm{HCB}$ & $\mathbf{0 . 2 6}$ *** & $*-\mathbf{0 . 4 9} * * *$ & $-0.37 * * *$ & $-\mathbf{0 . 4 3} * * *$ & $-0.21 * *$ & $-0.17 *$ & $-0.27 * * *$ & $-0.29 * * *$ & $-\mathbf{0 . 5 0} * * *$ & $-0.22 * *$ & $-\mathbf{0 . 3 0} * * *$ & $-0.21 * *$ \\
\hline p.p-DDE & 0.13 & $-\mathbf{0 . 2 9} * * *$ & $-0.22 * *$ & $-0.21 * *$ & $-0.24 * *$ & -0.11 & $-0.18 *$ & $-0.17 *$ & $-\mathbf{0 . 3 4} * * *$ & $-0.17 *$ & $-0.21 * *$ & $-0.15 *$ \\
\hline p.p-DDD & $0.17 *$ & $-0.37 * * *$ & $-\mathbf{0 . 1 9} * *$ & $-\mathbf{0 . 3 7} * * *$ & $-\mathbf{0 . 2 6} * * *$ & $-0.19 *$ & $-\mathbf{0 . 2 1} * *$ & $-0.22 * *$ & $-0.47 * * *$ & $-\mathbf{0 . 2 0} * *$ & $-0.16^{*}$ & -0.08 \\
\hline OCS & 0.07 & $-\mathbf{0 . 3 3} * * *$ & -0.09 & $-0.15^{*}$ & -0.07 & -0.13 & $-\mathbf{0 . 2 1} * *$ & $-0.26 * * *$ & $-0.20 * *$ & $-\mathbf{0 . 1 8} *$ & $-0.21 * *$ & $-0.17 *$ \\
\hline$\sum \mathrm{PCBs}$ & 0.10 & $-0.21 * *$ & $-0.18 *$ & $-\mathbf{0 . 2 2} * *$ & $-0.17 *$ & 0.04 & -0.04 & -0.03 & $-0.29 * * *$ & -0.08 & -0.09 & -0.05 \\
\hline
\end{tabular}

* $P<0.05$, ** $P<0.01, * * * P<0.001$

11. Production of reactive oxygen species (ROS) by head kidney leucocytes (baseline, and induced by phorbol myristate acetate, ROS-PMA) (Skouras et al. 2003)

12. Vitellogenin, concentration of vitellogenin in the plasma of male flounder (Dizer et al. 2003)

As some of these biomarkers, such as EROD and MAM, were influenced by the sex of the flounder (Broeg et al. 1999), only immature adult male flounder were used for all calculations (see Broeg et al. 1999).

Residue analyses

For a characterization of the sampling sites by their chemical pollution burden, samples of sediment and blue mussel (Mytilus edulis) tissue from the Elbe estuary, Eider estuary and Helgoland 
"Tiefe Rinne" were analysed for their heavy metal $(\mathrm{Hg}, \mathrm{Pb}, \mathrm{Cd}, \mathrm{Cu})$ and chlorinated hydrocarbon (see Tables 1,2) content. Analyses were carried out by a commercial laboratory that had undergone an intercalibration exercise (Handels- und Umweltschutzlaboratorium Dr. Wietz, Hamburg). A description of all parameters and the results of these analyses are given in Dizer et al. (2003).

For residue analyses of flounder, muscles samples were collected from the same flounder individuals that were also analysed for their parasite community and for biochemical biomarker responses. At each sampling site and during every sampling period, muscle tissue was collected from 10 individuals and analysed for the heavy metal $(\mathrm{Hg}, \mathrm{Pb}, \mathrm{Cd}, \mathrm{Cu})$ and chlorinated hydrocarbon content by a commercial laboratory (Labor für Fischgesundheit, Professor Harz, Bremerhaven; for details see Broeg et al. 1999; Schmolke et al. 1999).

Statistical analyses

In order to test for a relationship between flounder parasite infection parameters and site-specific contamination levels, sediment and blue mussel residue burdens from the sampling locations were used as sentinels. Correlation analyses were carried out between parasitological data and the sediment and blue mussel tissue residue measurements. For this analysis, the mean abundance of the parasite species and mean values of the community indices under study were calculated on the basis of infection parameters of 9-30 flounder individuals from the sampling site under study. These data were then compared to measurements of sediment residues and mean values of residue concentration in 5-10 blue mussels from the same location and collected during the same sampling period.

A relationship between parasitological parameters and contamination levels of individual fish was determined by correlation analyses between parasitological data and the residue burden measured in muscle tissue of the same flounder individuals.

All residue measurements with values below the detection limit were replaced by $2 / 3$ of the value of the detection limit, in order to include them in calculations (Schmolke et al. 1999).

To test whether a relationship between responses of contamination biomarkers and effects on the parasite community could be observed, correlation analyses of both data sets were performed, also based on measurements collected from individual fish.

All correlation analyses were done from pooled data collected over all the sampling periods and were carried out using Spearman's Rank Correlation (STATISTICA 6.0, StatSoft). Comparisons of groups were done using the Kruskal-Wallis test and Dunn's post hoc test (SigmaStat 2.0). To test for an influence of salinity, parasitological parameters from locations with differences in salinity as well as with similar salinity were compared using chisquare tests as described previously (Schmidt et al. 2003a).

\section{Results}

Parasite infection parameters and sediment or mussel residues

A correlation analysis of parasite infection parameters, such as abundance of parasite species and component community indices, to sediment or mussel tissue contamination levels indicated that the parasite fauna of flounder was influenced by the concentration of heavy metals and several chlorinated hydrocarbons at the sampling locations. The relative abundance of $A$. cornuta, Z. viviparus and C. heterochrous in flounder at a sampling site showed high negative correlation coefficients to the concentration of individual heavy metals and polychlorinated biphenyls (PCBs) in the sediment from the sampling locations (Table 1). This finding was even more pronounced when species richness or the number of heteroxenous species was considered (Table 1). The community measures ShannonWiener's index of diversity and inverse Simpson's index of diversity were only correlated to some heavy metal residues in the sediment (Table 1).

When residues in the tissue of M. edulis were considered, the abundance of $A$. cornuta, Z. viviparus and $C$. heterochrous in flounder was highly correlated to decreasing concentrations of cadmium, $\beta-\mathrm{HCH}$, p.p.-DDD and total PCBs (see Table 1). In addition, the community measures species richness, number of heteroxenous species, number of macroparasite individuals, Shannon-Wiener Index of Diversity and inverse Simpson Index also decreased with increasing concentrations of contaminant residues in mussel tissue (Table 1). In contrast to these findings, the abundance of Trichodina spp. increased on flounder from sampling sites with increasing xenobiotica loads (Table 1).

Parasite infection parameters of flounder were only correlated to those contaminants which showed a clear regional pattern. When the contamination data from mussel tissue were combined over the sampling period, the concentrations of $\beta$-HCH, p.p-DDE and p.p.-DDD were significantly higher in mussels from the Elbe estuary than from the other sites (Fig. 1). The concentrations of cadmium and total PCBs in the tissue of M. edulis decreased gradually in the order Elbe $>$ Eider $>$ Helgoland (Fig. 1).

\section{Flounder muscle}

When xenobiotic loads in the muscle of individual flounder were compared to infection parameters of the parasite fauna from the same individuals, correlations were observed between the concentration of several xenobiotics and the abundance of parasite species. With increasing concentrations of hexachlorobenzene (HCB), DDE, DDD, octachlor styrol (OCS) or PCBs in flounder filet, the abundance of A. cornuta, $C$. heterochrous, Lepeophtheirus pectoralis and Lernaeocera branchialis decreased (Table 2 ). In addition, community measures such as the number of parasite species, the number of macroparasite individuals, and Shannon Wiener's index of diversity indicated a decreasing parasite diversity with increasing contamination load in flounder muscle (Table 2). In contrast to observations on hydrocarbon loads, infection with parasitic copepods A. cornuta, Lepeophtheirus pectoralis and Lernaeocera branchialis increased with increasing concentrations of mercury in flounder filet (Table 2). The parasite infection data were correlated to those xenobiotics which showed regional differences in concentration (Fig. 2). Flounder from the Elbe estuary had higher residues of DDD, DDE, HCB and OCS than 
Fig. 1 Concentration of selected contaminants in blue mussel tissue (Mytilus edulis) at three sampling sites in the German Bight in the years 1999-2000. Given are box plots with median values (white square), 25th and 75 th percentiles (box) and range without outliers (lines). E Elbe, $I$ Inner Eider, $H$ Helgoland. Stars above box plots indicate significant differences of the site to all other sites ( $n=20$ /location, $* P<0.05$, ** $P<0.01, * * * P<0.001)$

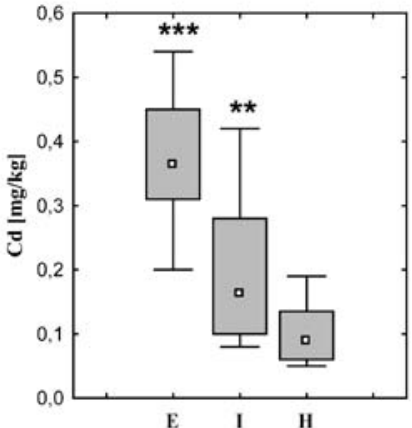

Mytilus edulis
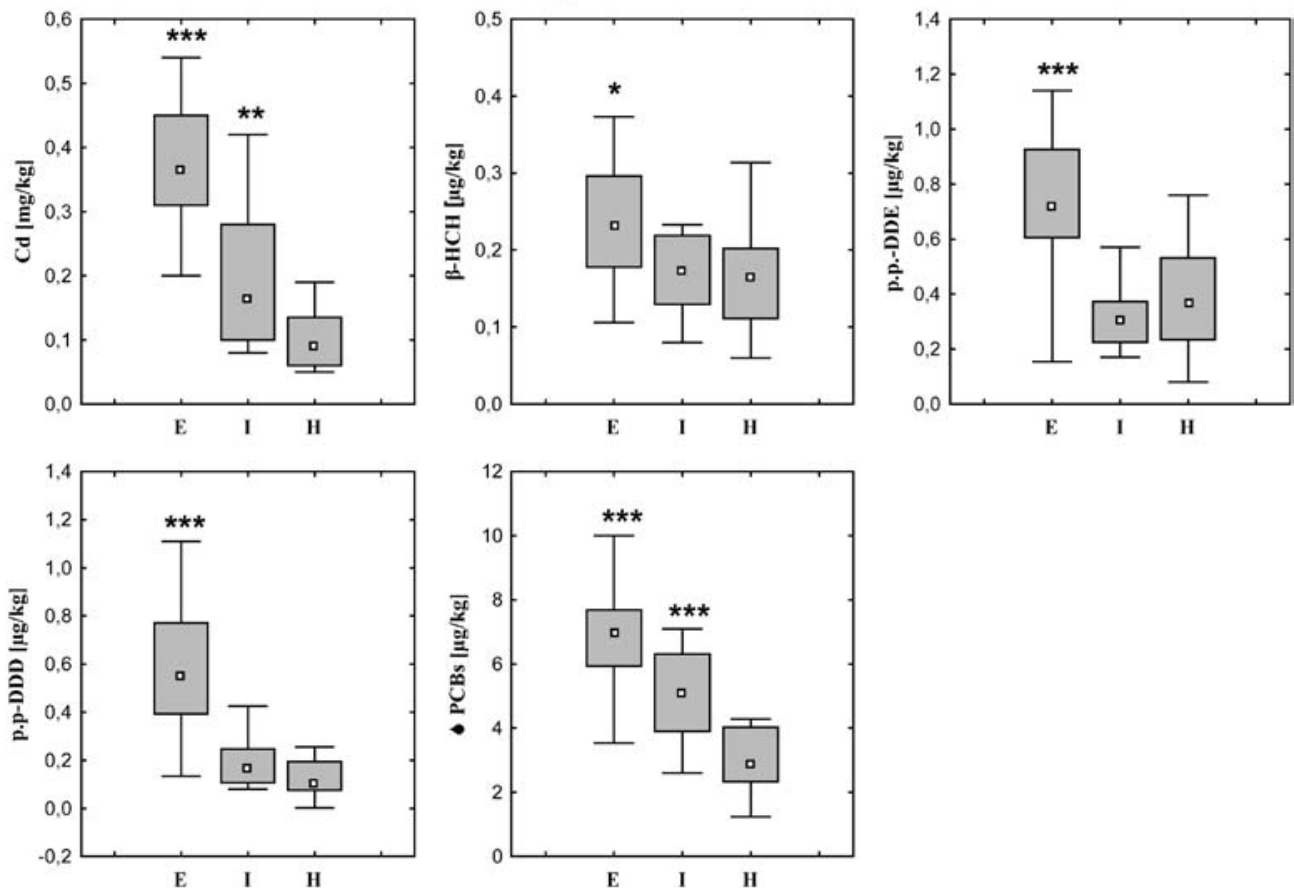

Platichthys flesus

2oncentration of selected contaminants in the muscle of flounder (Platichthys flesus) from five locations in the German Bight in the years 19992000. Given are box plots with median values (white square), 25th and 75th percentiles (box), range (lines) and outliers (black circle). $E$ Elbe, $O$ Outer Eider, $H$ Helgoland, $S$ Spiekeroog, $I$ Inner Eider $(n=185)$
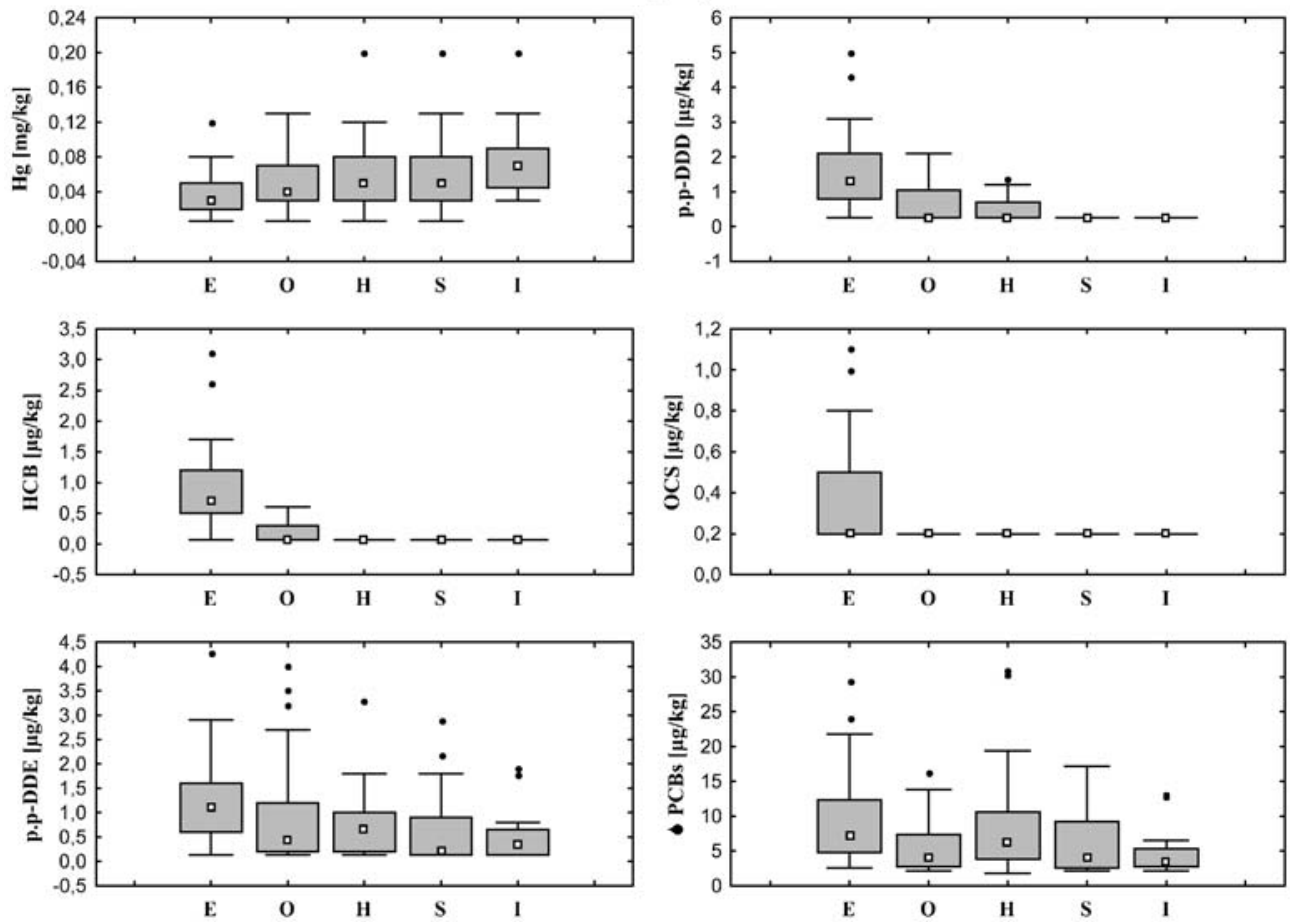

individuals from other sites. In contrast to this, the mercury concentration was lower in the flounder filet from the Elbe sampling site compared to individuals originating from other sampling locations (Fig. 2).

Correlation coefficients of parasite infection parameters to xenobiotic loads in the muscle of flounder were considerably lower than correlation coefficients obtained when the chemical contamination of the sediment or mussel tissue from the sampling location were considered (compare Tables 1 and 2). The abundance of the parasitic copepods A. cornuta, Lepeophtheirus pectoralis and Lernaeocera branchialis on individual flounder showed 
Table 3 Correlation analysis of parasite infection characteristics and biomarker responses of male flounder. Measurements taken from the same flounder individual were compared. Correlation coefficients and the level of significance are given. Significant correlations are additionally marked in bold. The majority of parameters were analysed from 1995 to 2000, see notes for exceptions. Abundance of the parasites: Acan Acanthochondria cornuta; Cuc Cucullanus heterochrous; Lep Lepeophtheirus pectoralis; Lern Lernaeocera branchialis; Met Metacercaria of an undetermined trematode species; Trich Trichodina spp.; Zoog Zoogonoides viviparus; $N$ number of macroparasite individuals; $S$ species richness; 1/D inverse Simpson's Index of diversity; $H^{\prime}$ Shannon-Wiener Index of diversity, $H_{s p}$ number of heteroxenous species. Biomarkers: $C h E-B r$ choline esterase activity in flounder brain; $C h E-f$ choline esterase activity in flounder muscle; $D N A-f$ DNA-unwinding, DNA strand breaks in hepatocytes; EROD activity of cytochrome P450 dependent monooxygenase ethoxyresorufin-O-deethylase; $L Y 1, L Y 2$ membrane stability of hepatocyte lysosomes; Lys lysozyme activity in flounder plasma; $M A A$ mean size of macrophage aggregates in flounder liver; $M A M$ activity of acid phophatase in macrophage aggregates of flounder liver; Pin uptake of neutral red by head kidney phagocytes; ROS production of reactive oxygen species by head kidney leucocytes, base line; ROS-PMA production of reactive oxygen species induced by phorbol myristate acetate; Vit concentration of vitellogenin in the plasma of male flounder

\begin{tabular}{|c|c|c|c|c|c|c|c|c|c|c|c|c|c|}
\hline $\begin{array}{l}\text { Bio- } \\
\text { marker }\end{array}$ & $\begin{array}{l}n \\
\text { (fish) }\end{array}$ & Trich & Acan & Lep & Lern & Meta & Zoog & Cuc & $S$ & $N$ & $H_{\mathrm{sp}}$ & $H^{\prime}$ & $1 / D$ \\
\hline EROD & 441 & $0.16 * * *$ & $-0.34 * * *$ & $-0.27 * * *$ & -0.08 & $\mathbf{- 0 . 1 9} * * *$ & $-0.10 *$ & $-0.10 *$ & $\mathbf{- 0 . 2 2} * * *$ & $\mathbf{- 0 . 2 0} * * *$ & \multicolumn{2}{|c|}{$-\mathbf{0 . 2 2} * * * \mathbf{- 0 . 3 3} * * *$} & $\mathbf{- 0 . 2 8} * * *$ \\
\hline MAM & 445 & $-0.12 *$ & $0.23 * * *$ & 0.06 & $0.24 * * *$ & 0.03 & 0.18*** & $0.15 * *$ & $0.24 * * *$ & $0.22 * * *$ & $0.25 * * *$ & $0.17 * * *$ & $0.13 * *$ \\
\hline Ly 1 & 444 & $-0.19 * * *$ & $0.20 * * *$ & 0.08 & 0.04 & 0.08 & $0.21 * * *$ & 0.07 & $0.11 *$ & $0.18 * * *$ & 0.06 & 0.11* & 0.09 \\
\hline Ly2 & 444 & $-0.21 * * *$ & $0.29 * * *$ & $0.16 * * *$ & $0.13 * *$ & $0.16 * * *$ & $0.12 * *$ & $0.10 *$ & $0.15 * *$ & $0.22 * * *$ & 0.09* & $0.18 * * *$ & $0.15 * *$ \\
\hline $\mathrm{ChE}-\mathrm{Br}{ }^{\mathrm{a}}$ & 138 & 0.04 & $-0.17 *$ & $-0.33 * * *$ & $0.25 * *$ & $-0.21 *$ & 0.13 & 0.03 & -0.14 & 0.14 & -0.06 & $-0.28 * * *$ & $-0.29 * * *$ \\
\hline ChE-f & 262 & 0.01 & 0.12 & 0.03 & 0.09 & 0.03 & -0.15 & 0.04 & 0.05 & 0.02 & 0.02 & -0.02 & -0.01 \\
\hline DNA-f & 262 & 0.06 & -0.12 & 0.06 & 0.04 & -0.06 & $-0.23 * * *$ & $-0.13 *$ & $-0.19 * *$ & -0.05 & -0.10 & -0.06 & -0.03 \\
\hline MAA & 445 & -0.06 & 0.04 & 0.04 & -0.03 & -0.05 & 0.06 & 0.04 & 0.03 & -0.01 & 0.07 & 0.08 & 0.07 \\
\hline Vit ${ }^{b}$ & 162 & 0.01 & -0.004 & $0.23 * *$ & 0.07 & -0.14 & -0.03 & 0.003 & -0.01 & 0.002 & -0.04 & 0.03 & 0.2 \\
\hline Pin ${ }^{b}$ & 158 & 0.13 & 0.16* & 0.01 & 0.02 & 0.19* & -0.07 & 0.06 & $0.22 * *$ & -0.01 & 0.10 & 0.15 & 0.14 \\
\hline $\operatorname{ROS}^{\mathrm{b}}$ & 165 & $-0.16 *$ & 0.10 & 0.07 & -0.01 & $-0.19 *$ & 0.11 & 0.09 & -0.07 & 0.003 & -0.07 & 0.12 & 0.11 \\
\hline ROS-PMA $^{\mathrm{b}}$ & b 165 & -0.10 & 0.18* & 0.05 & 0.15 & -0.02 & $0.20 *$ & 0.12 & 0.03 & 0.18* & -0.05 & 0.04 & 0.02 \\
\hline Lys ${ }^{b}$ & 181 & -0.12 & $0.30 * * *$ & $0.34 * * *$ & $0.18 *$ & -0.13 & $0.32 * * *$ & 0.08 & $0.17 *$ & $0.24 * * *$ & 0.13 & $0.21 * *$ & $0.22 * *$ \\
\hline
\end{tabular}

* $P<0.05, * * P<0.01, * * * P<0.001$

${ }^{a}$ Samples taken from 1995 to 1997

b Samples taken from 1999 to 2000

Fig. 3 Selected biomarker responses of flounder (P. flesus) at five locations in the German Bight in the years 1995-2000. ChE-Br were analysed from 1995-1997 and Lys from 19992000 only. Given are box plots with median values (white square), 25th and 75th percentiles (box), range without outliers (lines). $E$ Elbe, $O$ Outer Eider, $H$ Helgoland, $S$ Spiekeroog, I Inner Eider. Asterisks above box plots in the graphs for EROD, MAM and LY2 indicate significant differences of the marked station to Outer Eider, Helgoland and Spiekeroog, and above box plots in the graph for Lys of the marked station to Elbe, Outer Eider and Inner Eider $(P<0.001)$. The number of fish used for calculations is indicated to the right of each graph

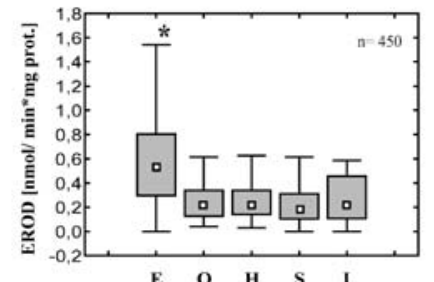

\section{Biomarker responses}
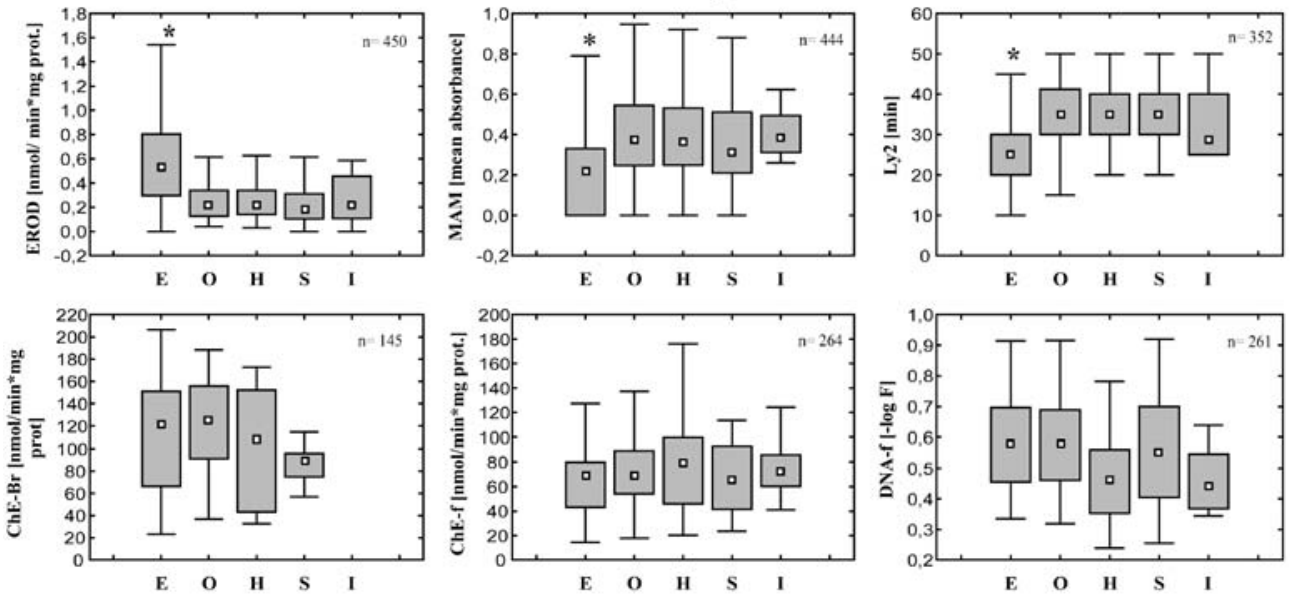

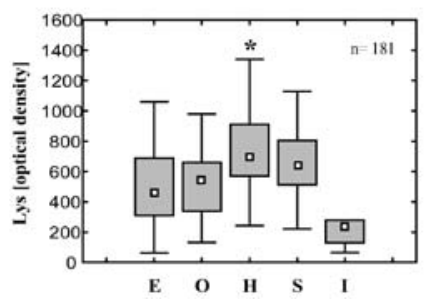

a clear correlation to contamination concentrations in flounder muscle (Table 2). The abundance of the gutdwelling parasites $C$. heterochrous and $Z$. viviparus was also lower in flounder individuals with increased HCB, DDD, DDE or OCS loads (Table 2), but correlation

coefficients were much higher when the mean abundance of these parasites on flounder from each sampling site were compared to the presence of xenobiotics in the sediment at that particular site (Table 1). 


\section{Biomarkers}

Of the biomarkers studied, only EROD, MAM, LY2, $\mathrm{ChE}-\mathrm{Br}$ and Lys showed correlation to more than half of the parasite infection parameters (Table 3). While the abundance of most of the parasite species under study and the parasite diversity parameters decreased with increasing measurements of EROD or $\mathrm{ChE}-\mathrm{Br}$, the values of parasite infection parameters were positively correlated to measurements of the indicators MAM, LY2 and Lys (Table 3). The abundance of Trichodina spp., however, increased with elevated EROD activity and decreased with increasing levels of MAM, LY1, LY2 or ROS.

When the EROD, MAM and LY2 data from all samples during 1995 to 2000 were combined, a clear regional pattern was evident (Fig. 3). The EROD activity was significantly higher in flounder from the Elbe estuary compared to individuals from all other sites, while MAM and LY2 were significantly reduced in individuals from the Elbe sampling location $(P<0.001)$. In this analysis, no significant differences between sampling sites were found for ChE-Br, ChE-f or DNA-F (Fig. 3). Levels of plasma lysozyme activity were significantly lower in flounder from the Elbe and Outer and Inner Eider estuary than in individuals from Helgoland $(P<0.001)$, but these measurements were only available from samples taken during 1999 and 2000.

\section{Discussion}

An indispensable prerequisite for biological effect monitoring which aims at testing pollution effects is the proper selection of sampling sites. They should be situated in the same ecological area but should differ in their pollution levels.

The German Bight, which was taken as an ecological area in the present study, is mainly influenced by the river Elbe, which is the major freshwater source for this area. The Elbe delivers about $43 \%$ of the total freshwater input into the international Wadden Sea, but also holds a key position for the southern North Sea as a pollution source (de Jong et al. 1999). In comparison, the river Eider is a relatively small freshwater source and only moderately polluted. While the Elbe is mainly affected by industrial pollution like heavy metals, chlorinated hydrocarbons and nutrients, the anthropogenic influence at the Eider estuary is more due to agricultural activities (Schmolke et al. 1999).

In the years 1980-1985, there was a strong reduction in the heavy metal influx into the German Bight via rivers, which led to an overall reduction in the heavy metal contamination in the Wadden Sea, converging to the natural background level of most metals (van Landwüst and Anders 1996; de Jong et al. 1999). In addition, the PCB concentration decreased between $45 \%$ and $85 \%$ from 1985 to 1996 (van Landwüst and Anders 1996; de Jong et al. 1999). Thus, compared to other polluted locations in the North Sea, contamination levels in the German Bight are low (Herut et al. 1999).

Although the concentrations of a large number of chemicals ranged close to or were below the detection limit at all sampling sites (Dizer et al. 2003), a regional pattern could be observed in the concentration of some contaminants. Schmolke et al. (1999) confirmed a decreasing contamination gradient for heavy metals in sediments and mussel tissue in the order Elbe $>$ Eider $>\mathrm{Hel}-$ goland for the years 1996 and 1997. The same gradient was also described for the PCB content of birds' eggs in the Wadden Sea (de Jong et al. 1999). These gradual differences in the contamination load of the sediment was not clearly evident when the sampling locations were compared to each other for 1999-2000 (Dizer et al. 2003). It could only be confirmed that sediments from Helgoland were less contaminated than those from Elbe or Outer Eider. In contrast, in mussel tissue, a contamination gradient with Elbe $>$ Eider $>$ Helgoland could be confirmed for the cadmium and PCB contents. For other contaminants, such as DDD, DDE and $\mathrm{HCH}$, such a gradient could not be established. The concentrations of theses contaminants were, however, significantly higher in the tissue of mussels from the Elbe estuary than from all other locations.

Contaminants which exhibited spatial differences in concentration could be correlated to infection parameters of flounder parasites.

In particular, the following infection parameters were found to be correlated to residue data of sediment and mussel tissue: abundances of selected parasite species, species richness and diversity decreased with increasing contamination levels (Schmidt et al. 2003a, 2003b). When these infection parameters were considered, gradual differences between the sampling locations in the order Elbe $<$ Eider $<$ Helgoland became evident when chemical and parasitological data from the entire observation period from 1995 to 2000 were combined (Schmidt et al. 2003a, 2003b). These findings indicate that parasite infection parameters collected over a period of several years integrate annual fluctuations and thus can serve as reliable indicators of an impact of xenobiotic contamination on the environment under study.

Whether spatial differences in the distribution of parasites found in the German Bight were related to anthropogenic influences or were caused by natural factors, such as temperature or salinity, is a very important question. It has to be answered when parasites are being considered as indicators in environmental pollution monitoring (Kennedy 1997; Overstreet 1997). Salinity is an important factor which influences the distribution pattern of parasites between estuarine and offshore sites (Gibson 1972; Möller 1978; Wichowski 1990; MacKenzie et al. 1995). In the present study, the parasite community of flounder included several species which are considered to be marine species. Their distributions are known to be limited by decreasing salinity (see Möller 1978). Differences in parasite abundances between flounder from the Elbe estuary and from 
coastal or offshore sites (see Schmidt et al. 2003a) might therefore be a result of salinity effects. This could not, however, explain the gradual differences in parasite abundances in flounder from the sampling sites Elbe estuary, Outer Eider estuary and Helgoland. Neither could it explain the differences between the estuarine sites, Elbe and Inner Eider, which had comparable salinity characteristics. In addition, concentrations of individual xenobiotics in sediment and mussel tissue collected at the fish sampling sites (Schmolke et al. 1999, Dizer et al. 2003) showed numerous correlations to parasite infection data. Only a few infection parameters were correlated to salinity measurements of the sampling sites. This suggests that, in addition to salinity, the distribution pattern of parasites in the German Bight is indeed affected by regional contamination levels.

Further laboratory studies on parasite responses to water bodies with different contamination levels, as well as to tide-dependent, regular changes of water salinity, could help to quantify the impact of salinity or pollutionrelated influences on parasite distribution.

In several studies (Yeomans et al. 1997; Palm and Dobberstein 1999; Madsen et al. 2000) Trichodina spp. were discussed as potential biomarkers for effects of organic contamination. Recent studies have suggested that the presence and intensity of trichodinids on fish from a particular site largely depend on the presence of small algae, organic matter and bacterial biomass at the site under consideration (Lom 1995; Yeomans et al. 1997; Broeg et al. 1999; Palm and Dobberstein 1999; Madsen et al. 2000). In the present study, trichodinids were most abundant on flounder from the estuarine sites, Elbe and Inner Eider. The content of organic matter in the water column was not measured, but from other monitoring programmes conducted in the same area at the same time (de Jong et al. 1999) it could be concluded that the nutrient concentration in the Elbe and Eider estuary was about 2-10 times above background levels found at, for instance, the Helgoland location. Thus, the presence of trichodinids on flounder from the estuarine sites was most probably related to an increased abundance of organic matter at these sites rather than to elevated residues of xenobiotics, and therefore the findings of the present study might support the concept of trichodinids as indicators of organic pollution.

When residues of heavy metals and hydrocarbons in flounder muscle were considered, a contamination gradient among the sampling sites could not be established (Kress et al. 1999; Schmolke et al. 1999). At all sampling sites, flounder individuals with elevated contamination levels were found together with individuals which harboured low residue concentrations. Schmolke et al. (1999) concluded that the regional effects, which were described for sediments and mussel tissue, might have been blurred in fish tissue by migratory activities of flounder from the Elbe into areas of the German Bight with deeper waters. Nevertheless, when pooled residue data from 1999-2000 were considered, individual flounder with elevated concentrations of specific contaminants were more frequently collected from the Elbe estuary than from other locations (Broeg, unpublished data). When the concentrations of individual contaminants in flounder muscle were compared to parasite infection parameters, correlations were found to all parasitological parameters considered. Thus, the present investigation indicates that the contamination load of individual fish had an impact on the parasite community of that particular individual. In general, the correlation coefficients of xenobiotic concentrations in flounder muscle and parasite infection parameters were not as high as those found for sitespecific pollution. Surprisingly, the highest correlation coefficients were found between muscle residues and infection characteristics of ectoparasitic copepods, including Lepeophtheirus pectoralis and Lernaeocera branchialis. The abundance of these two species was not correlated to site-specific contamination levels and was not gradually different between the sites. This suggested that the abundance of these ectoparasitic copepods is mainly influenced by contaminants gained by the individual, while the presence of $A$. cornuta and gut-dwelling helminths such as $Z$. viviparus and $C$. heterochrous is affected by site-specific pollution.

An indication of an effect of the contamination concentration in individual fish on infection parameters of parasites can also been read from the responses of biochemical or physiological biomarkers of exposure to xenobiotics. In the framework of the present investigations, responses of these biomarkers were recorded from the same fish individuals which were subjected to chemical and parasitological analysis (see Dizer et al. 2003; Skouras et al. 2003; Broeg, unpublished data). In particular, the activity of choline esterase in the brain of flounder (ChE-Br), EROD activity of liver cells, the activity of acid phosphatase in macrophage aggregates in flounder liver (MAM), the stability of lysosomal membranes in hepatocytes (LY2) and the activity of plasma lysozyme (Lys) were correlated to the abundance of parasites, including Lepeophtheirus pectoralis and Lernaeocera branchialis, or community measurements. Biomarkers in hepatocytes, such as EROD activity or stability of lysosomal membranes, are considered to reflect the health status of fish, while parasite infection parameters indicate habitat conditions (Adams 2002). Correlations of biomarker responses to parasite infection parameters might then support the conclusion that an analysis of the parasite community can serve to determine pollution-induced environmental damage.

In a multivariate analysis of responses of different biomarkers for pollution, the above-mentioned biochemical parameters allowed health-impaired flounder to be separated from unimpaired individuals (Schmolke et al. 1999). In this analysis, the formation of health clusters failed when the parameter species richness of the parasite community was used. In the framework of the present investigation, pollution effects on the composition of the parasite community became evident only when observations were combined over a period of several years. Biochemical biomarkers of exposure, such as EROD 
activity or stability of lysosomal membranes, are considered to respond quickly to contaminants (Broeg et al. 1999, 2002; Schlenk and Di Giulio 2002), while changes in the parasite community become evident much later. Therefore, while biochemical parameters are discussed as immediate indicators of chemical exposure, changes in the composition of the parasite community in fish related to habitat deterioration have the potential to indicate longer-lasting influences. Hepatic EROD activity and lysosomal membrane stability in flounder from the present investigation responded mainly to contaminant exposure (Broeg, unpublished data). This response occurred quickly, which even allowed the identification of single pollution events (Broeg et al. 2002). In contrast to this, parasite infection parameters varied within wide ranges between single sampling points or years (Schmidt et al. 2003a). But when data from several years were combined, these infection parameters allowed site-specific differences to be identified very precisely (Schmidt et al. 2003a, 2003b, present communication). Thus, fish parasite communities are well suited as bioindicators of environmental challenge as defined by Adams (2002) and van der Oost et al. (2003). These bioindicators should be measures of ecological significance and integrate effects of various stressors over large spatial or temporal scales (Adams 2002; van der Oost et al. 2003).

On a longer timescale, changes in the parasite community of fish have been described for various habitats and species: Pseudopleuronectes americanus in the Atlantic (Burn 1980), Platichthys flesus from the Baltic Sea (Sulgostowska 1988) and various fish, crustacean and molluscan hosts from the Baltic Sea (Kesting and Zander 2000). Similar studies have also been performed on the parasite community of Siganus rivulatus from the Mediterranean Sea, and of Liza ramada and $L$. aurata from the Red Sea (Diamant, unpublished data; Dzikowski, unpublished data). These studies have shown that, over decades, the species diversity had decreased as a consequence of deteriorating environmental conditions due to urban and industrial pollution. The present study was undertaken over a 6-year period only, and over this short time interval overall changes in parasite diversity could not be discerned at any of the sampling sites (for results see Schmidt et al. 2003a). The observation period, however, allowed spatial differences in the abundance of individual parasite species to be determined, as well as spatial differences in community data between different sampling locations in the German Bight, despite seasonal and annual fluctuations (for results, see Schmidt et al. 2003a, 2003b). The findings of the present investigations could not, surprisingly, be compared to the situation in earlier decades, because studies on the parasite community of flounder from the German Bight are completely lacking, even though flounder is a preferred species for use in environmental monitoring.

\section{Conclusions}

The present study gives indications that the fish parasite community is a valuable tool for the assessment of ecological consequences of chemical contamination in a habitat. Correlations of parasite community measures or abundance of parasite species to the concentration of selected chemicals in sediment or M. edulis samples from the same sampling location showed that the fish parasite community can serve as a measure for the level of environmental challenge at a specific site. Decreased parasite community measures were found to correspond to elevated concentrations of chlorinated hydrocarbon residues in flounder filets and increased responses of biochemical biomarkers for exposure to xenobiotics. These observations underline that, in an integrated biological effect monitoring programme, the analysis of parasite communities is a valuable tool for the assessment of ecological consequences of environmental deterioration at the population and community level. Acute or chronic responses of selected biochemical, histopathological, physiological and immunological biomarkers confirm the impact of pollutants on the fish host. Corresponding changes in parasite community measures to biomarker responses, however, establish a link from mechanistic processes at the sub-cellular level of individual fish to the ecological significance of pollution on the population and community levels of biological organisation, which is represented by dynamics in the parasite community.

Acknowledgements The authors thank Heike Nachtweh and Martina Borchardt for technical assistance during the sampling procedure. We also thank Captain C. Lührs and his crew of the RV "Uthörn" for sampling of the flounder and the Alfred-Wegener Institute, Bremerhaven, for providing laboratory facilities at the Biologische Anstalt Helgoland. The present study was supported by the German Ministry of Education and Science (BMBF code 03F0159A).

\section{References}

Adams SM (2002) Biological indicators of aquatic ecosystems stress: introduction and overview. In: Adams SM (ed) Biological indicators of aquatic ecosystem stress. American Fisheries Society, Bethesda, Md., pp1-11

Broeg K, Zander S, Diamant A, Körting W, Krüner G, Paperna I, von Westernhagen $H$ (1999) The use of fish metabolic, pathological and parasitological indices in pollution monitoring, I. North Sea. Helgol Mar Res 53:171-194

Broeg K, Köhler A, von Westernhagen H (2002) Disorder and recovery of environmental health monitored by means of lysosomal stability in liver of European flounder (Platichthys flesus L.). Mar Environ Res 54:1-4

Burn PR (1980) Pollution effects on fish parasites. Coastal Ocean Pollut Assess News 1:3-4

Bush AO, Lafferty KD, Lotz JM, Shostak AW (1997) Parasitology meets ecology on its own terms: Margolis et al. revisited. J Parasitol 83:575-583

Dizer H, Fischer B, Bresler V, Unruh E, Krüner G, Broeg K, von Westernhagen H, Levikov S, Baumert H, Hansen P-D (2003) Neurotoxic, genotoxic, immunotoxic and endocrine effects of 
fish and molluscs in the North Sea, Mediterranean Sea and Red Sea. Helgol Mar Res (in press)

Gelnar M, Sebelová S, Dusek L, Koubová B, Jurajda P, Zahrádková $S$ (1997) Biodiversity of parasites in freshwater environment in relation to pollution. Parassitologia 39:189-199

Gibson DI (1972) Flounder parasites as biological tags. J Fish Biol 4:1-9

Herut B, Kress N, Shefer E, Hornung H (1999) Trace element levels in mollusks from clean and polluted coastal marine sites in the Mediterranean, Red and North Seas. Helgol Mar Res 53:154-162

Jong F de, Bakker JF, van Berkel CJM, Dankers NMJA, Dahl K, Gätje C, Marencic H, Potel P (1999) Wadden Sea quality status report. Wadden Sea Ecosystem No. 9. Common Wadden Sea Secretariat, Wilhelmshaven, Germany

Kennedy CR (1997) Freshwater fish parasites and environmental quality: an overview and caution. Parassitologia 39:249-254

Kesting V, Zander CD (2000) Alterations of the metazoan parasite faunas in the brackish Schlei Fjord (Northern Germany, Baltic Sea). Int Rev Hydrobiol 85:325-340

Khan RA, Payne JF (1997) A multidisciplinary approach using several biomarkers, including a parasite, as indicators of pollution: a case history from a paper mill in Newfoundland. Parassitologia 39:201-238

Khan RA, Thulin J (1991) Influence of pollution on parasites of aquatic animals. Adv Parasitol 30:201-238

Kress N, Herut B, Shefer E, Hornung H (1999) Trace element levels in fish from clean and polluted coastal marine sites in the Mediterranean Sea, Red Sea and North Sea. Helgol Mar Res 53:163-170

Landwüst C van, Anders K (1996) Fischkrankheiten in der Nordsee. Umweltbundesamt Texte 57/96. Umweltbundesamt, Berlin, Germany

Lom J (1995) Trichodinidae and other ciliates (phylum Ciliophora). In: Woo PTK (ed) Fish diseases and disorders, vol 1. Protozoan and metazoan infections. CAB, London, pp229-262

MacKenzie K, Williams HH, Williams B, McVicar AH, Siddall R (1995) Parasites as indicators of water quality and the potential use of helminths transmission in marine pollution studies. Adv Parasitol 35:86-144

Madsen HCK, Buchmann K, Mellergaard S (2000) Association between trichodiniasis in eel (Anguilla anguilla) and water quality in recirculation systems. Aquaculture 187:275-281

Magurran AE (1988) Ecological diversity and its measurements. Princeton University Press, Princeton, N.J.
Möller H (1978) The effects of salinity and temperature on the development and survival of fish parasites. J Fish Biol 12:311323

Oost R van der, Beyer J, Vermeulen NPE (2003) Fish bioaccumulation and biomarkers in environmental risk assessment: a review. Environ Toxicol Pharmacol 13:57-149

Overstreet RM (1997) Parasitological data as monitors of environmental health. Parassitologia 39:169-175

Palm HW, Dobberstein RC (1999) Occurrence of trichodinids ciliates (Peritrichia: Urceolariidae) in the Kiel Fjord, Baltic Sea, and its possible use as a biological indicator. Parasitol Res $85: 726-732$

Schlenk D, Di Giulio RT (2002) Biochemical responses as indicators of aquatic ecosystem health. In: Adams SM (ed) Biological indicators of aquatic ecosystem stress. American Fisheries Society, Bethesda, Md., pp13-42

Schmidt V, Zander S, Körting W, Steinhagen D (2003a) Parasites of flounder (Platichthys flesus) from the German Bight, North Sea, and their potential use in biological effects monitoring. A. Infection characteristics of potential indicator species. Helgol Mar Res (in press)

Schmidt V, Zander S, Körting W, Steinhagen D (2003b) Parasites of flounder (Platichthys flesus) from the German Bight, North Sea, and their potential use in biological effects monitoring. B. Community structure and fish parasite biodiversity. Helgol Mar Res (in press)

Schmolke SR, Broeg K, Zander S, Bissinger V, Hansen PD, Kress N, Herut B, Jantzen E, Krüner G, Sturm A, Körting W, von Westernhagen H (1999) Multivariate statistical approach to the temporal and spatial patterns of selected bioindicators observed in the North Sea during the years 1995-1997. Helgol Mar Res 53:257-266

Skouras A, Dizer H, Hansen PD, Broeg K, von Westernhagen H, Steinhagen D (2003) The use of innate immune responses as biomarkers in a program of integrated biological effects monitoring on flounder (Platichthys flesus L.) from the southern North Sea. Helgol Mar Res (in press)

Sulgostowska $T$ (1988) Changes of the parasite fauna of the flounder Platichthys flesus dependent on the degree of pollution of the southwest Baltic Sea. Wiad Parazytol 34:591-594

Wichowski F-J (1990) Parasites as indicators of flounder Platichthys flesus (L.) migrations in the lower Elbe River. Fischökologie 2:1-26

Yeomans WE, Chubb JC, Sweeting RA (1997) Use of protozoan communities for pollution monitoring. Parassitologia 39:201212 